\title{
Biochemical Status of Stock Plants and Their Annual Sprouts as a Crucial Key for Successful Adventitious Root Formation
}

\author{
Gregor OSTERC*, Franci ŠTAMPAR, Valentina SCHMITZER \\ University of Ljubljana, Biotechnical Faculty, Chair for Fruit Growing, Viticulture and Vegetable Growing, Jamnikarjeva 101, 1000 Ljubljana, \\ Slovenia; gregor.osterc@bf.uni-lj.si("correspondingauthor);franci.stampar@bf.uni-lj.si;valentina.schmitzer@bf.uni-l.si
}

\begin{abstract}
Leafy cuttings of Prunus subbirtella Miq. 'Autumnalis' were harvested from mature, semi-mature and juvenile stock plants at four dates during the vegetative period 2011 (on $16^{\text {th }}$ of May, on $30^{\text {th }}$ of May, on $20^{\text {th }}$ of June and on $11^{\text {th }}$ of July) and their auxin levels (IAA, IAA-Asp) and sugar content (glucose, sucrose, sorbitol) were quantified. The IAA and IAA-Asp contents in cutting bases increased over the vegetative period, whereby aspartate values were higher than IAA values. The IAA-Asp values ranged from $6.3 \mu \mathrm{g} \mathrm{g}^{-1}$ to $22.7 \mu \mathrm{g} \mathrm{g}^{-1} \mathrm{FW}$ and reached two great peaks on $30^{\text {th }}$ of May and on $11^{\text {th }}$ of July. The IAA values ranged from $0.29 \mu \mathrm{g} \mathrm{g}^{-1}$ to $4.51 \mu \mathrm{g} \mathrm{g}^{-1} \mathrm{FW}$, reaching a small fall on $20^{\text {th }}$ of June. Significantly higher levels of IAA and IAA-Asp were measured at the base of mature cuttings compared to cuttings of semi-mature and juvenile origin, when the cuttings were harvested on $30^{\text {th }}$ of May and on $11^{\text {th }}$ of July. On the other hand, mature leafy cuttings accumulated significantly less fructose and glucose in their root emergence zone $\left(16.3 \mathrm{~g} \mathrm{~kg}^{-1} \mathrm{DW}, 45.2 \mathrm{~g} \mathrm{~kg}^{-1} \mathrm{DW}\right)$ compared to semi-mature cuttings $\left(26.4 \mathrm{~g} \mathrm{~kg}^{-1}\right.$ DW, $62.5 \mathrm{~g} \mathrm{~kg}^{-1} \mathrm{DW}$ ) and juvenile cuttings $\left(27.3 \mathrm{~g} \mathrm{~kg}^{-1} \mathrm{DW}, 73.9 \mathrm{~g} \mathrm{~kg}^{-1} \mathrm{DW}\right.$ ). All measured rooting parameters (rooting success, number of main roots and root length) were significantly improved when cuttings of a more juvenile origin (semimature and juvenile) were used.
\end{abstract}

Keywords: indole-3-acetic acid, N-(3-indolacetyl) aspartic acid, severance date, maturation, juvenility, rhizogenesis, carbohydrate content

Abbreviations: adventitious rooting $=$ AR, adventitious root formation $=$ ARF, indole-3-acetic acid = IAA, IAA-Aspartate $=$ IAA-Asp

\section{Introduction}

Stock plant quality plays a very important role in the adventitious root formation (ARF) process. In herbaceous plants, optimal nutrition, irrigation and various horticultural measures are essential for achieving healthy and vigorous stock plants. However, in addition to the optimization of technological procedures, the physiological status of stock plants is crucial for ARF in woody plants (Hartmann et al., 1997; Spethmann, 1997; Osterc, 2009; Rasmussen and Hunt, 2010). An optimal physiological status of stock plants can significantly improve the rooting success of leafy cuttings (Rasmussen and Hunt, 2010). Nevertheless, the understanding of physiological ageing of woody plants remains fairly incomplete (Osterc, 2009) although it is tightly linked to economical results of the horticultural production (Dodd and Power, 1988; Spethmann, 1997). A very important segment in the understanding of woody plant maturation process is the possibility of reversing the mature plants into juvenile ones. In vitro propagation methods serve as an excellent possibility of generating physiologically juvenile plant material which is genetically identical as the original stock plant but rejuvenated in order to achieve optimal rooting success. ARF is namely significantly improved when juvenile instead of mature stock plant material is used for propagation of leafy cuttings in different woody plant species (Spethmann, 1997; Morgan and Williams, 1976; Plietsch and Heiliger, 1997; Osterc et al., 2009; Osterc and Štampar, 2011).

Biochemical research of adventitious rooting $(\mathrm{AR})$ has been focused on determining the levels of indole-3-acetic acid (IAA), the main compound affecting adventitious rooting process. Several research studies have confirmed that IAA can affect the AR process either by endogenous IAA levels measured in cuttings at the time of severance or by induced IAA metabolism during the induction and initiation phase of AR (Osterc et al., 2009; Ford et al., 2001; Nag et al., 2001). Endogenous IAA level of severed cuttings is directly connected to stock plant ability to accumulate IAA (Osterc et al., 2009). As already known, environmental conditions play a crucial role, because only plants, grown under optimal conditions can accumulate enough endogenous IAA necessary for subsequent rooting(Hartmann $e t$ al., 1997). The physiological status of stock plants and their parts is also very important as juvenility/maturity greatly influences IAA accumulation in woody plants (Osterc, 2009). However, only a few studies stressed the importance of this parameter in the past. Osterc et al. (2009) measured IAA accumulation in root emergence zone of ornamental cherry leafy cuttings at the time of severance and determined significant differences among different physiological origin of the cuttings. 
230

Also, the accumulation of different sugars, affected by physiological status of stock plants, can be of potential interest. In woody plants, the involvement of sugars in the process of $A R$ is a little controversial. High sugar contents quantified in annual shoots of mature and juvenile stock plants showed optimal photosynthesis and sufficient supply with nutrients. Therefore it cannot be concluded that carbohydrates have a regulatory role in rooting potential of leafy cuttings per se (Veierskov, 1988; Druege et al., 2000; Druege, 2009).

The aim of this study was to determine the accumulation of IAA and IAA-Aspartate (IAA-Asp) in annual sprouts of stockplants during the vegetation period. The analysed areas on the sprouts were their bases because they represented zones of root induction process, when the cuttings were prepared. The question weather the intensity of auxin accumulation in annual shoots could be affected either by severance date or by different physiological status of the stock plants has been solved. Additionally, the content of sugars in annual shoots was measured at the severance point and their levels compared among of stock plants of different physiological status. This represents a new aspect of studying different backgrounds of root induction process including the physiological status of the material (sprouts) serving for cutting preparation. Therefore, this aspect can be an interesting chapter in adventitious root formation physiology in woody species.

\section{Materials and methods}

\section{Plantmaterial}

Ornamental cherry (Prunus subbirtella Miq.) cultivar 'Autumnalis' leafy cuttings were harvested from different stockplants, distinguished by their physiological status. Three treatments were established: (1) mature plants, more than 40-yearold cherry plants; (2) semi-mature plants, 5-year-old plants propagated by leafy cuttings obtained from mature cherry plants; and (3) juvenile plants, 5-year-old in vitro derived plants (rejuvenated above mentioned mature cherry stock plants). All plants were located at the experimental field of Biotechnical Faculty in Ljubljana (Slovenia) to ensure equal environmental conditions.

Mature stock plants were rarely pruned (only dry branches), whereas semi-mature and juvenile stock plants were pruned every spring. Therefore, mature plants were up to $10 \mathrm{~m}$ height, semimature and juvenile plants were bushy, up to $1.5 \mathrm{~m}$ height. Leafy cuttings were harvested four times during the growing period: on $16^{\text {th }}$ of May, $30^{\text {th }}$ of May, $20^{\text {th }}$ of June and $11^{\text {th }}$ of July. The propagation material was always adjusted to $12 \mathrm{~cm}$ long leafy cuttings with apical meristems. On average, the cuttings had three to four fully developed leaves.

\section{Cuttingpropagation}

The cuttings were inserted in the substrate mixture of peat and sand (1:1) without any hormone treatment. Prior to insertion, the substrate mixture was fertilized with a slow-release fertilizer $\left(2.0 \mathrm{gl}^{-1}\right.$ $3-4 \mathrm{M}$ Osmocote ${ }^{\circledR}$ Exact $16+11+11+3 \mathrm{Mg}+\mathrm{Te}$; Scotts International, Heerlen, The Netherlands), and the $\mathrm{pH}$ value was adjusted to 4.0 with dolomitic lime. All experimental treatments (cuttings from mature, semi-mature and juvenile stock plant material) were replicated 3 times with 11 cuttings per plot (3 cuttings per plot for auxin analyses, 8 cuttings for rooting evaluation and sugar analyses).
The experiment was set in an unheated plastic house equipped with a fogging system (Plantfog-Befeuchtungsanlagen Nebelsysteme, Fishamend, Austria). The air temperatures in the plastic house reached up to $50^{\circ} \mathrm{C}$ during daytime and ranged between 18 and $20{ }^{\circ} \mathrm{C}$ during the night. The substrate temperature (rooting zone) did not undergo such oscillations (between 20 and $24^{\circ} \mathrm{C}$ ), mainly due to a quality fogging system. Fogging was regulated manually to obtain $90-95 \%$ relative humidity. Fogging intervals lasted approx. $30 \mathrm{~s}$, with a $60 \mathrm{~s}$ pause and were switched off during the night $(19.00-07.00 \mathrm{~h})$.

The evaluation of propagation success was always performed four weeks after severance. The number of successfully rooted leafy cuttings, and main roots were counted and the root bush length was measured.

\section{Extraction and analyses of LAA and LAA-Asp}

Leafy cuttings (three cuttings per treatment for each sampling date) for auxin analysis were collected on the day of severance and immediately transferred to laboratory facilities. All leaves were cut off and discarded and only the basal parts (root emergence zone, lower $3 \mathrm{~cm}$ of the cuttings) were used for further analysis. The samples were washed and stored at $-20^{\circ} \mathrm{C}$ until the analysis were performed.

Auxins were extracted following the methods of Štefančic et al. (2005), Kovač et al. (2003) and Goncalves et al. (2008). Samples were ground to a fine powder using a mortar and pestle with liquid nitrogen. Each sample was divided into two portions, $0.15 \mathrm{~g}$ each, and extracted separately with $1 \mathrm{ml} \mathrm{BHT}-\mathrm{MeOH}$ solution [0.5 g of BHT (2,6-di-tert-butyl-4-methylphenol) per 11 solution] and $4 \mathrm{ml} 5 \mathrm{mM}$ potassium phosphate buffer, adjusted to $\mathrm{pH}$ 6.5. After $1 \mathrm{~h}$ at $4^{\circ} \mathrm{C}$, the extract was filtered and $3 \mathrm{ml} 5$ $\mathrm{mM}$ potassium phosphate buffer ( $\mathrm{pH}$ value 6.5) was added to each sample. For auxins purification, Strata C18-E columns (pore size $55 \mu \mathrm{m}$, retention capacity $500 \mathrm{mg}$, tube size $6 \mathrm{ml}$; Phenomenex, Torrance, CA, USA) were used. The complete sample extracts were first run through the column preconditioned with potassium phosphate buffer ( $\mathrm{pH}$ value 6.5) and then washed with $4 \mathrm{ml}$ of $5 \mathrm{mM}$ potassium phosphate buffer ( $\mathrm{pH}$ value 6.5). The eluate was acidified to $\mathrm{pH}$ value 2.5 with $0.5 \mathrm{M} \mathrm{H}_{3} \mathrm{PO}_{4}$, then transferred to a second column preconditioned with potassium phosphate buffer ( $\mathrm{pH}$ value 2.5). The column was rinsed with $2 \mathrm{ml}$ twice-distilled water and eluted with $2 \mathrm{ml} 80 \%(\mathrm{v} / \mathrm{v})$ methanol.

The concentrated eluate $(1 \mathrm{ml})$ was separated by TSP (Thermo Separation Products) HPLC using a Chromsep (Varian, Palo Alto, CA, USA) column [SS $250 \times 4.6 \mathrm{~mm}$, Hypersil 5 ODS (Octa Decyl Silica)] and analysed by a fluorescence (Spectrasystem FL2000; SpectraPhysics, San Jose, CA, USA) and a UV-VIS detector (K-2500; Knauer, Berlin, Germany). The mobile phase consisted of solvent A (acetonitrile/glacial acetic acid/twice-distilled water, 10/2/88, $\mathrm{v} / \mathrm{v})$ and solvent B (100\% acetonitrile). The gradient was isocratic from $84 \%$ solvent $A$ and $16 \%$ solvent $B$ the first $20 \mathrm{~min}$ to $95 \%$ solvent $\mathrm{A}$ and $5 \%$ solvent $\mathrm{B}$ for the rest of the $30 \mathrm{~min}$ method, and the flow rate was $1 \mathrm{ml} / \mathrm{min}$. Excitation of the fluorescence detector was set at $292 \mathrm{~nm}$ and emission at $360 \mathrm{~nm}$. The UV-VIS detector was adjusted to measure absorption at $280 \mathrm{~nm}$ (Goncalves et al., 2008). IAA and IAA-Asp were quantified by fluorimetry, comparing peak areas with those of corresponding standards. Losses were evaluated by standards that had passed through the extraction and purification processes. 
Table 1. Rooting, number of main roots and root bush length of Prunus subbirtella 'Autumnalis' leafy cuttings of different physiological origin propagated on four severance dates

\begin{tabular}{|c|c|c|c|c|}
\hline Severance date & Physiological status & Rooting (\%) & Number of roots (n) & Length of roots $(\mathrm{cm})$ \\
\hline \multirow{3}{*}{$16^{\text {th }}$ of May } & Mature & $100.0 \pm 0 c$ & $6.0 \pm 2.3 \mathrm{ab}$ & $2.8 \pm 1.2 \mathrm{abc}$ \\
\hline & Semi-mature & $100.0 \pm 0 \mathrm{c}$ & $20.3 \pm 11.2 c$ & $5.5 \pm 1.2 \mathrm{cdef}$ \\
\hline & Juvenile & $100.0 \pm 0 c$ & $25.7 \pm 8.1 \mathrm{~cd}$ & $6.9 \pm 2.5 \mathrm{ef}$ \\
\hline \multirow{3}{*}{$30^{\text {th }}$ of May } & Mature & $86.7 \pm 11.5 c$ & $6.0 \pm 5.5 \mathrm{ab}$ & $2.3 \pm 2.4 \mathrm{ab}$ \\
\hline & Semi-mature & $100.0 \pm 0 c$ & $24.2 \pm 5.6 \mathrm{~cd}$ & $8.1 \pm 1.5 f$ \\
\hline & Juvenile & $100.0 \pm 0 \mathrm{c}$ & $29.4 \pm 10.7 \mathrm{de}$ & $7.3 \pm 1.6 \mathrm{ef}$ \\
\hline \multirow{3}{*}{$20^{\text {th }}$ of June } & Mature & $26.7 \pm 23.1 \mathrm{a}$ & $3.3 \pm 0 \mathrm{a}$ & $3.5 \pm 0 \mathrm{abcd}$ \\
\hline & Semi-mature & $60.0 \pm 20.0 \mathrm{~b}$ & $3.6 \pm 3.1 \mathrm{a}$ & $3.0 \pm 1.1 \mathrm{abc}$ \\
\hline & Juvenile & $60.0 \pm 20.0 \mathrm{~b}$ & $11.3 \pm 3.5 b$ & $7.8 \pm 2.8 \mathrm{f}$ \\
\hline \multirow{3}{*}{$11^{\text {th }}$ of July } & Mature & $48.9 \pm 25.2 \mathrm{ab}$ & $4.1 \pm 4.2 \mathrm{ab}$ & $1.7 \pm 1.2 \mathrm{a}$ \\
\hline & Semi-mature & $100.0 \pm 0 c$ & $19.5 \pm 6.9 c$ & $4.9 \pm 2.3 \mathrm{bcde}$ \\
\hline & Juvenile & $95.8 \pm 7.2 \mathrm{c}$ & $33.2 \pm 7.5 \mathrm{e}$ & $6.1 \pm 1.5 \mathrm{def}$ \\
\hline
\end{tabular}

Auxins were identified using a mass spectrometer (Thermo Scientific, LCQ Deca XP MAX) with an atmospheric-pressure chemical ionization (APCI) operating in positive ion mode. The analyses were carried out using full scan data-dependent $\mathrm{MS}^{\mathrm{n}}$ scanning from $m / z 50$ to 1000 . The injection volume was $10 \mu \mathrm{l}$ and the flow rate maintained at $1.0 \mathrm{ml} \mathrm{min}$. The capillary temperature was $275^{\circ} \mathrm{C}$, the sheath gas and auxiliary gas were 35 and 10 units respectively; and the source voltage was $16 \mathrm{kV}$. Spectral data were elaborated using the Excalibur software (Thermo Scientific). The identification of compounds was confirmed by comparing retention times and their spectra as well as by adding the standard solution to the sample and by fragmentation. Calculated auxin contents (IAA and IAA-Asp) of each sample $(\mathrm{n}=3)$ were the means of two replicate measurements and were expressed in $\mu \mathrm{gg}^{-1} \mathrm{FW}$.

\section{Sugar analyses}

Individual sugar contents (glucose, fructose and sorbitol) were measured in leafy cutting root emergence zone at the day of severance and samples were prepared as described previously for auxin analyses. Samples were lyophilised and between $0.3 \mathrm{~g}$ and 2.0 $\mathrm{g}$ material was ground to a fine powder using mortar and pestle. Plant material was immersed in 3 to $20 \mathrm{ml}$ of twice-distilled water (depending on the amount of plant material used) and left for extraction for $30 \mathrm{~min}$ at room temperature with frequent stirring. The extracted samples were centrifuged at $10000 \times g_{\mathrm{n}}$ for $7 \mathrm{~min}$ at $10^{\circ} \mathrm{C}$ (Eppendorf Centrifuge 5810R, Hamburg, Germany). The supernatant was filtered through a $0.45 \mu \mathrm{m}$ filter (MachereyNagel), transferred to a vial and stored at $-20^{\circ} \mathrm{C}$ until analysis by high-performance liquid chromatography (HPLC; Thermo Scientific, Finnigan Spectra System, Waltham, MA, USA). For each analysis, $20 \mu \mathrm{l}$ of sample was used. The analysis of sugars was carried out using a Rezex-RCM-monosaccharide column $(300 \times 7.8 \mathrm{~mm}$; Phenomenex, Torrance, CA) with a flow rate of $0.6 \mathrm{ml} / \mathrm{min}$ and column temperature maintained at $65^{\circ} \mathrm{C}$. For the mobile phase, twice-distilled water was used, and an RI (refractive index) detector for identification. The identification and quantification of individual carbohydrates were calculated with the addition of corresponding external standards and expressed in $\mathrm{gkg}$ ${ }^{1} \mathrm{DW}$.

\section{Statistical analyses}

Statistical analyses were carried out with the Statgraphics Plus (version 4.0) programme, using analyses of variance (ANOVA).
Statistically significant differences between treatments (date of severance and physiological status) were tested with the Duncan test at a 0.95 confidence level.

\section{Results}

\section{Rooting}

Rooting success was evaluated four weeks after insertion into the substrate. Cuttings obtained from mature cherry stock plants rooted significant poorer than more juvenile cuttings on all severance dates, except on $16^{\text {th }}$ of May, when the rooting was $100 \%$ in all treatments. Rooting results clearly indicate that the difference in rooting percentage between mature cuttings and rejuvenated cuttings (by propagation or in vitro rejuvenation) increased at later severance dates (Table 1). Root development is a clear factor of successful rooting and cuttings from rejuvenated stock plants (semi-mature and juvenile) developed more roots, which were also longer compared to cuttings obtained from mature stock plants (Table 1). Up to 30 roots with a length exceeding $8 \mathrm{~cm}$ were visible on semi-mature and juvenile cuttings and there were significant differences among different severance dates (Table 1).

\section{LAA and LAA-Asp}

The levels of free IAA in cutting bases ranged from 0.29 to $4.51 \mathrm{\mu g} \mathrm{g}^{-1} \mathrm{FW}$ during the growing season. The IAA values slightly increased over the season, with expect on $20^{\text {th }}$ of June, when a little fall was noticed. The aspartate levels in cutting bases reached in general higher levels than IAA and ranged from 6.3 to $22.7 \mathrm{\mu g} \mathrm{g}^{-1} \mathrm{FW}$. The levels increased over the season with two great peaks, on $30^{\text {th }}$ of May and on $11^{\text {th }}$ of July (Fig. 1). Unexpectedly high levels of IAA were quantified in the root emergence zone of mature leafy cuttings. The values ranged between 0.23 and $12.72 \mu \mathrm{g} \mathrm{g}^{-1} \mathrm{FW}$ in mature cuttings and were significantly higher on the $30^{\text {th }}$ of May and on the $11^{\text {th }}$ of July compared to cuttings obtained from semi-mature and juvenile stock plants (Fig. 2). The IAA-Asp profile was very similar to that of IAA. Again, the base of cuttings severed from mature cherry stock plants contained more aspartate compared to more juvenile cuttings at all sampling dates. IAA-Asp profile reached two peaks, on $30^{\text {th }}$ of May and on $11^{\text {th }}$ of July when the concentrations of 41.3 and $56.8 \mathrm{\mu g} \mathrm{g}^{-1} \mathrm{FW}$ were significantly higher than those measured in semi-mature and juvenile cuttings at the same time (Fig. 3). 


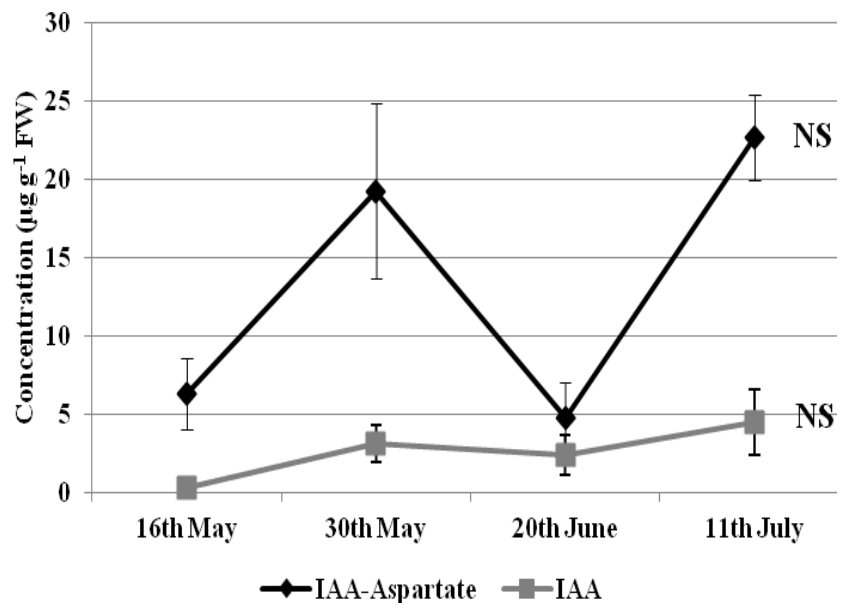

Fig. 1. IAA and IAA-Aspartate level at the base of Prunus subbirtella 'Autumnalis' leafy cuttings on different severance dates during the growing season 2011. Means \pm standard error are shown. NS assigns no significant differences at $P<=0.05$, Duncan test

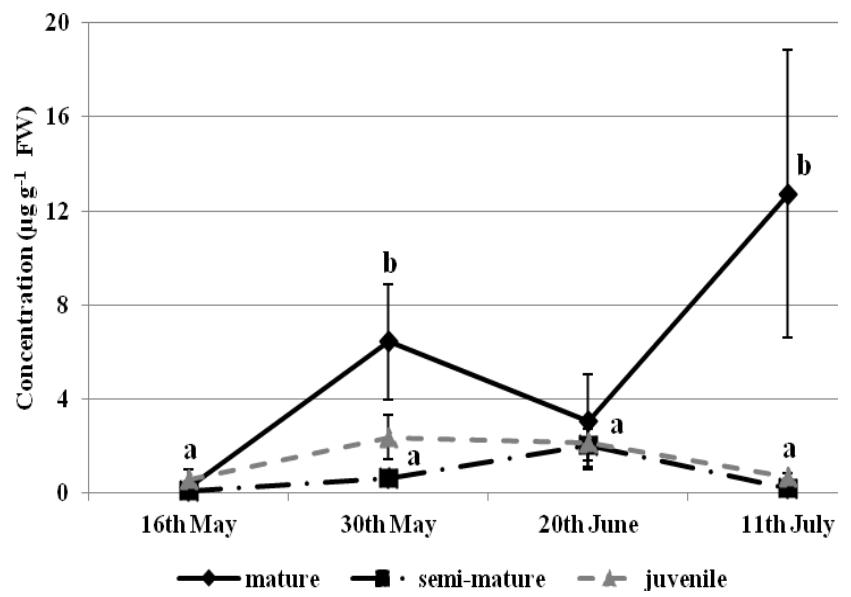

Fig. 2. IAA content level at the base of Prunus subbirtella 'Autumnalis' leafy cuttings of different physiological origin on four severance dates. Means \pm standard error are shown. Different letters assign significant differences for each set of dates individually at $P<=0.05$, Duncan test

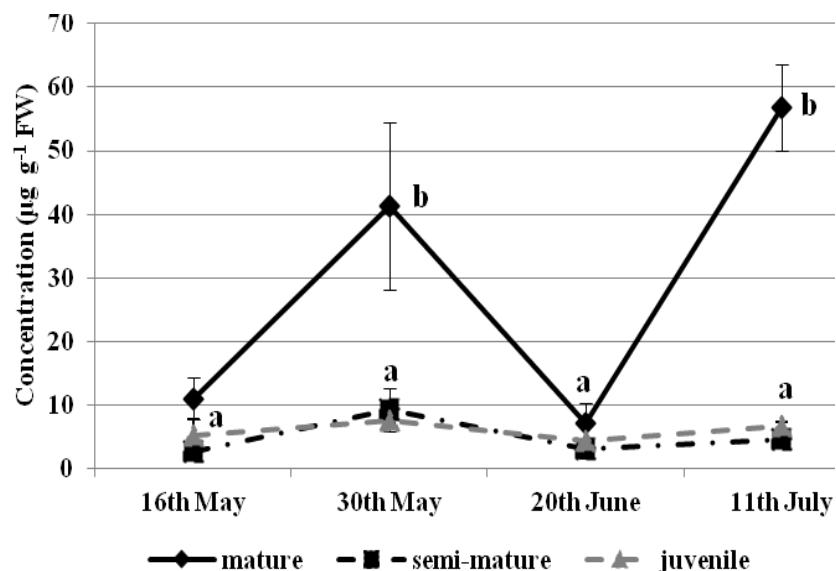

Fig. 3. IAA-Aspartate content level at the base of Prunus subbirtella 'Autumnalis' leafy cuttings of different physiological origin on four severance dates. Means \pm standard error are shown. Different letters assign significant differences for each set of dates individually at $P<=0.05$, Duncan test
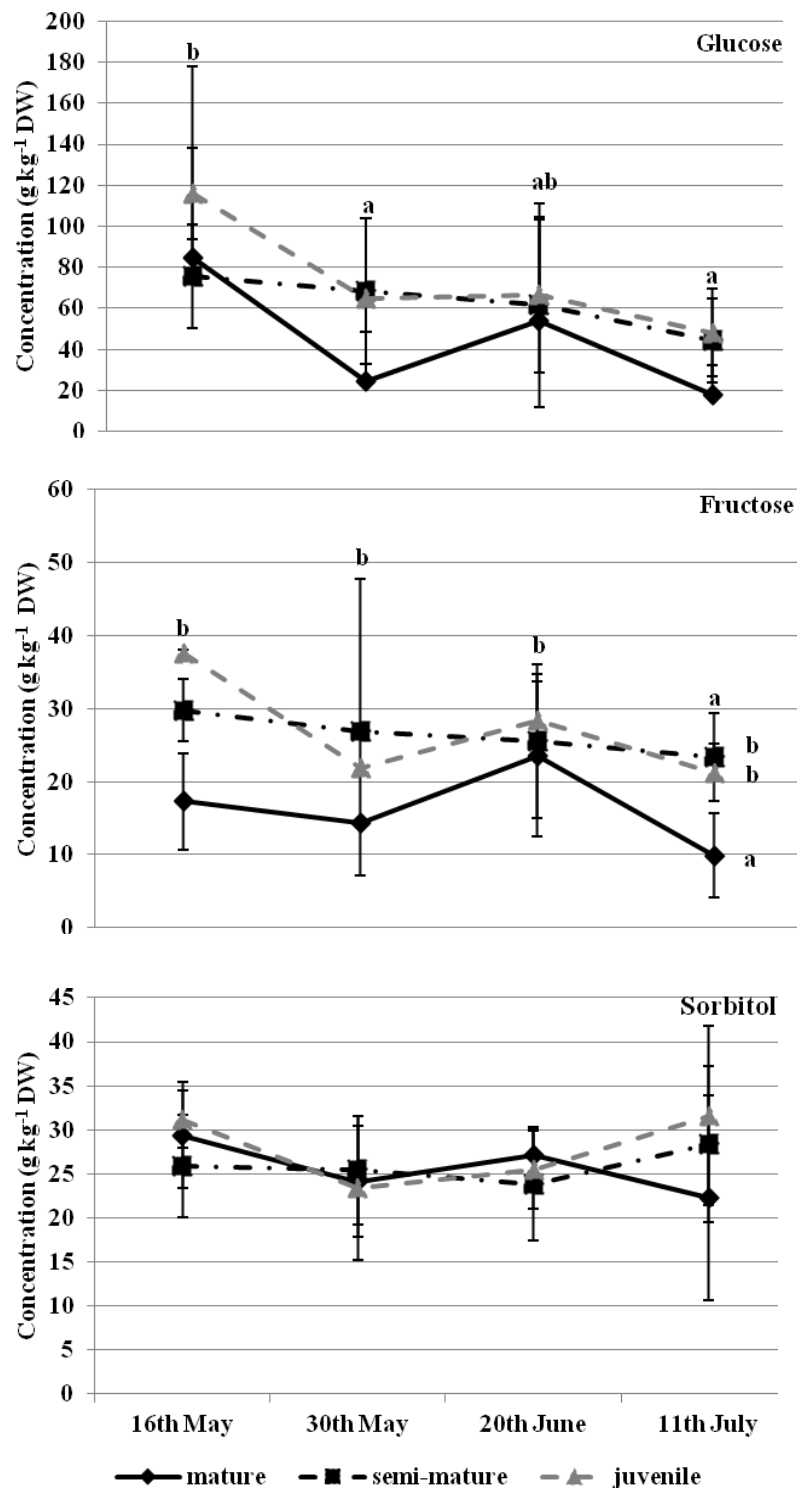

Fig. 4. Content level of different sugars at the base of Prunus subbirtella 'Autumnalis' leafy cuttings of different physiological origin on four severance dates. Means \pm standard error are shown. Different letters assign significant differences for each set of dates individually at $P<=0.05$, Duncan test

\section{Sugars}

Glucose and fructose content levels measured at the base of ornamental cherry leafy cuttings decreased during the vegetative period, whereas sorbitol content was similar during the whole analysed period. Glucose levels decreased from $92.1 \mathrm{~g} \mathrm{~kg}^{-1} \mathrm{DW}$ at $16^{\text {th }}$ of May to $36.7 \mathrm{~g} \mathrm{~kg}^{-1} \mathrm{DW}$ at $11^{\text {th }}$ of July. Fructose content was even lower and a decrease from $28.2 \mathrm{~g} \mathrm{~kg}^{-1} \mathrm{DW}$ in the middle of May to $18.2 \mathrm{~g} \mathrm{~kg}^{-1} \mathrm{DW}$ in the middle of July was measured. Fructose content levels also differed among different physiological origin of the cuttings. Cuttings from mature cherry stock plants accumulated significantly less fructose $\left(16.3 \mathrm{~g} \mathrm{~kg}^{-1}\right.$ DW) compared to cuttings severed from semi-mature $(26.4 \mathrm{~g} \mathrm{~kg}$ ${ }^{1}$ DW) and juvenile stock plants (27.3 $\left.\mathrm{g} \mathrm{kg}^{-1} \mathrm{DW}\right)$. A similar glucose profile was established among treatments but the differences were not significant (Fig. 4). 


\section{Discussion}

The rooting results obtained in this study clearly support well known data on great differences in rooting success between mature and juvenile cutting material from numerous previous reports (Spethmann, 1997; Morgan and Williams, 1976; Plietsch and Heiliger, 1997; Osterc et al., 2009). An excellent rooting result of ornamental cherry juvenile cuttings was recorded regardless on the severance date. On the other hand, mature cuttings rooted well only on the first severance date and a decreased rooting ability was noted later in the vegetative period. The number of roots also showed the same trend. Rooting profile of mature cuttings was similar to the rooting profile of specific difficult-to-root cuttings reported in some previous studies (Ford et al., 2001). Therefore, it can be concluded that the importance of the optimal rooting conditions for successfully rooting increase strongly with the maturation status of stock plants. According to our results, semi-mature cuttings reacted similarly as juvenile cuttings and their rooting capacity was less affected by severance date.

Nevertheless, horticultural and forestry history deals with many experiments, which stress the importance of optimal severance date for subsequent rooting in numerous plant species (Spethmann, 1997; Ford et al., 2001; Osterc et al., 2007). Ford et al. (2001) showed that the percent transport of IAA, the intensity and the velocity of hormone transport declined over the growing season. The decline was in this experiment especially strong in lilac, classified as difficult-to-root species. Spethmann (1997) could show in his experiments that lilac leafy cuttings could be rooted with the highest ratio at the beginning of the growing season, immediately before flowering. In our experiment the IAA concentrations in cutting bases slightly increased over the growing season (except on $20^{\text {th }}$ of June) but together with the IAA also the concentrations of IAA-Asp increased. The rooting results were in average the highest at the beginning of the growing season, when the IAA concentration was at the lowest level, but also the concentration of IAA-Asp, which is signed as IAA inactivation compound (Bartel et al., 2001), was also at the lowest level at the same time.

Differences in rooting success were often explained with genetic variation among species. Ford et al. (2001) categorised lilac as a difficult-to-root species and Forsythia as an easy-to-root genus. Osterc et al. (2007) ascribed oscillations in rooting response and callus formation between two chestnut cultivars to intraspecific clone differences. However, biochemical patterns, characteristic of difficult- and easy-to-root species, have rarely been studied. Ford et al. (2001) ascribed differences in rooting success of lilac and Forsythia to differences in IAA transport ability to annual shoots. Moreover, Osterc et al. (2007) quantified various polyphenolic compounds in chestnut cuttings and indicated that differences exist among cultivars and also among different severance dates, but the differences were not always significant.

In the present study, however, auxin levels (IAA and IAAAsp content) differed significantly between mature cuttings and cuttings obtained from more juvenile ornamental cherry plants on all sampling dates. Similarly, differences in rooting success were measured among treatments with the exception of $20^{\text {th }}$ of June. At that time both IAA content levels and rooting response of leafy cuttings of all three physiological types were similar.
The accumulation of high levels of IAA and IAA-Asp was unexpected in mature cuttings especially in relation to lower auxin levels quantified in juvenile material which rooted better. Based on the findings of Ford et al. (2001), great rooting differences between mature and more juvenile cuttings in our experiment cannot be explained by a weaker polar IAAtransport in mature cuttings. The IAA over-accumulation in mature cuttings led to poorer rooting due to the inhibitory effect of high IAA content levels on ARF. A similar reaction has already been reported in herbaceous plants (Faivre-Rampant et al., 2002), but in woody plants it has not been demonstrated previously. Faivre-Rampant et al. (2002) explained poor rooting results of tobacco rac shoots with the inhibitory effect of the supra-optimal concentration of active auxin at the time of AR. Marks et al. (2002) reported a potential stress reaction of difficult-to-root woody species (such as lilac) which transported exogenously applied IAA with greater intensity compared to easier-to-root Forsythia cuttings. Štefančič et al. (2005) also stressed the importance of the optimal IAA content levels in the rooting material during the first hours after severance in order to achieve ideal subsequent rooting. Cherry cultivars with supraIAA content levels namely showed poorer rooting potential. Moreover, different biochemical compounds may trigger various regulatory mechanisms in woody plants. Osterc et al. (2008) reported higher content levels of various polyphenolic compounds in chestnut cuttings and linked them to a better rooting potential. The type of a regulatory mechanism of the specific compound depends on the type of function which this compound has in a plant. Over-accumulation of aspartat in the mature cuttings at the time of severance indicates that a large part of auxin remains inactive. This can be explained by high levels of IAA-Asp, which can potentially inactivate IAA activity (Bartel et al., 2001) and thus directly influencing the rooting success.

Carbohydrates (glucose and fructose) serve as a nutritional storage and thus a higher content levels measured in juvenile cuttings could be linked to their better rooting ability. Higher levels of sugars namely boost the development of roots, which consequently represent a stronger sink for different nutrients. Druege et al. (2000) demonstrated that a higher sucrose: starch ratio in leaves of chrysanthemum cuttings at the time of severance increased rooting at specific severance dates. On the other hand, Druege (2009) also stressed that the initial carbohydrate reserves in chrysanthemum cuttings are less important for subsequent rooting when the photosynthesis of cuttings after inserting in the substrate is sufficient for normal plant and root development. Based on some previous data, it can be assumed, that juvenile cuttings are able to photosynthesise on much higher levels compared to mature cuttings (Teiz and Zeiger, 2006). Higher initial carbohydrate reserves and a higher level of photosynthesis of juvenile cuttings both represent a sufficient nutrient pool for successful subsequent rooting.

\section{Conclusions}

The correct time of severance of specific plant species and cultivars is closely correlated with the endogenous auxin level in cutting material. Understanding the regulatory effect of the endogenous IAA level in mature cuttings led us to conclude that the optimal level of endogenous IAA at the time of severance is of crucial importance for subsequent rooting 
234

potential. Beside IAA level also levels of other conjugates, especially those who inactivate the IAA action (like IAAAsp) is of great importance. The quantification of the ideal IAA level of specific propagation material is surely the next step to take. Answers to these questions can only be elucidated by monitoring different plant groups and their physiological status which is the work of our future.

\section{Acknowledgement}

This work is a part of the Programme Horticulture No. P4-0013-0481 granted by the Slovenian Research Agency.

\section{References}

Bartel B, LeClere S, Magidin M, Zolman BK (2001). Inputs to the active indole-3-acetic acid pool: de novo synthesis, conjugate hydrolysis, and indole-3-butyric acid $\beta$-oxidation. J Plant Growth Regul 20:198-216.

Dodd RS, Power AB (1988). Clarification of the term Topophysis. Silvae Genet 37:14-15.

Druege U (2009). Involvement of carbohydrates in survival and adventitious root formation of cuttings within the scope of global horticulture, p. 187-208. In: Niemi K, Scagel C (Eds.). Adventitious root formation of forest trees and horticultural plants - from genes to applications. Research Signpost, Kerala, India.

Druege U, Zerche S, Kadner R, Ernst M (2000). Relation between nitrogen status, carbohydrate distribution and subsequent rooting of chrysanthemum cuttings as affected by pre-harvest nitrogen supply and cold-storage. Ann Bot-London 85:687-701.

Faivre-Rampant O, Charpentier JP, Kevers C, Dommes J, van Onckelen H, Jay-Allemand C, Gaspar T (2002). Cuttings of the non-rooting $\mathrm{rac}$ tobacco mutant overaccumulate phenolic compounds. Funct Plant Biol 29:63-71.

Ford YY, Bonham EC, Cameron RWF, Blake PS, Judd HL, HarrisonMurray RS (2001). Adventitious rooting: examining the role of auxin in an easy- and a difficult-to-root plant. Plant Growth Regul 36(2):149-159.

Goncalves JC, Diogo G, Coelho MT, Vidal N, Amancio S (2008). Quantitation of endogenous levels of IAA, IAAsp and IBA in micro-propagated shoots of hybrid chestnut pre-treated with IBA. In Vitro Cell Dev Biol-Plant 44:412-418.

Hartmann HT, Kester DE, Davies FT Jr, Geneve RL (1997). Plant propagation: Principles and practices. 6th ed. Prentice Hall, New Jersey, $770 \mathrm{p}$.

Kovač M, Piskernik D, Ravnikar M (2003). Jasmonic acid-induced morphological changes are reflected in auxin metabolism of beans grown in vitro. Biol Plantarum 47:273-275.
Marks TR, Ford YY, Cameron RWF, Goodwin C, Myers PE, Judd HL (2002). A role for polar auxin transport in rhizogenesis. Plant Cell Tiss Org 70:189-198.

Morgan DL, McWilliams EL (1976). Juvenility as a factor in propagating Quercus virginiana Mill. Acta Hort 56:263-268.

Nag S, Saha K, Choudhuri MA (2001). Role of auxin and polyamines in adventitious root formation in relation to changes in compounds involved in rooting.J Plant Growth Regul 20:182-194.

Osterc G (2009). A change in perspective: Stockplant qualities that influence adventitious root formation of woody species, p. 175-185. In: Niemi K, Scagel C (Eds.). Adventitious root formation of forest trees and horticultural plants - from genes to applications. Research Signpost, Kerala, India.

Osterc G, Štampar F (2011). Differencies in endo/exogenous auxin profile in cuttings of different physiological ages. J Plant Physiol 168:2088-2092.

Osterc G, Štefančič M, Solar A, Štampar F (2007). The effect of severance date and rooting ability of chestnut cuttings and associated changes in phenolic contents during adventitious root formation. Phyton-Ann Rei Bot A 46:285-294.

Osterc G, Štefančič M, Solar A, Štampar F (2008). Phenolic contents in cuttings of two clones of hybrid chestnut (Castanea crenata $\times$ Castanea sativa) in the first days after cutting severance. Acta Agr Scand B-S P 58:162-168.

Osterc G, Štefančič M, Štampar F (2009). Juvenile stock plant material enhances root development through higher endogenous auxin level. Acta Physiol Plant 31:899-903.

Plietzsch A, Heiliger P (1997). In-vitro-vermehrte Mutterpflanzen den konventionellen überlegen. Deutsche Baumschule 2:62-64.

Rasmussen A, Hunt MA (2010). Ageing delays the cellular stages of adventitious root formation in pine. Australian Forestry 73:41-46.

Spethmann W (1997). Autovegetative Gehölzvermehrung, p. 382-449. In: Krüssmann W (Ed.). Die Baumschule. Parey Verlag, Berlin, Germany.

Štefančič M, Štampar F, Osterc G (2005). Influence of IAA and IBA on root development and quality Prunus $\triangle$ GiSelA 5' leafy cuttings. Hortscience 40:2052-2055.

Teiz L, Zeiger E (2006). Plant Physiology. 4th ed. Sinauer Associates, Massachusetts, $764 \mathrm{p}$.

Veierskov B (1988). Relation between carbohydrates and adventitious root formation, p. 70-78. In: Davis TD, Haissig BE, Sankhla N (Eds.). Adventitious root formation in cuttings. Dioscorides Press, Oregon, USA. 